\title{
Лексикографическое описание тувинских пословиц: принципы, структура, этнолингвокультурологический комментарий (на европейском паремиологическом фоне)
}

\author{
Михаил А. Бредис \\ Российский университет дружбы народов, Российская Федерация, \\ Евгений Е. Иванов \\ Могилёвский государственный университет имени А. А. Кулешова, Республика Беларусь, \\ Ольга В. Ломакина \\ Московский педагогический государственный университет; Российский университет дружбы народов, \\ Российская Федерация, \\ Наталия Ю. Нелюбова \\ Российский университет дружбы народов, Российская Федерация, \\ Шенне Ю. Кужугет \\ Тувинский государственный университет, Российская Федерация
}

Отсутствие типологических описаний тувинских пословиц создаёт искусственную изоляцию тувинского пословичного фонда, который является органичной частью общего евразийского паремиологического континуума, характеризуется как общими с другими языками, так и уникальными пословицами, маркирующими этнокультурную специфику тувинского народа. Наибольшую актуальность (и наибольшую трудность) в этой связи представляет собой лексикографическое описание тувинских пословиц на европейском паремиологическом фоне.

Цель исследования - разработать методологические основания для лексикографического описания тувинского пословичного фонда на фоне европейских пословиц (принципы, структура, этнолингвокультурологический комментарий).

Фактическим материалом послужили издания тувинских пословиц и поговорок, примеры пословиц из словарей, а также наиболее авторитетные паремиологические словари современных европейских языков (Э. Штрауса, Д. Пацолаи, К. Григаса, В. М. Мокиенко, М. Ю. Котовой и др.).

В статье разработаны принципы словарного описания тувинских пословиц на широком европейском языковом фоне, которое проводится на основе теории структурно-семантического моделирования, предполагающей последовательную дифференциацию единиц тувинского пословичного фонда по критерию общности / специфичности в сравнении с пословицами европейских языков на полностью vs. частично аналогичные и абсолютно vs. коррелятивно уникальные (по структурносемантической модели); частичные аналоги на этнолингво vs. этнокультурно ассимилированные; коррелятивные уникалии на этнолингво vs. этнокультурно маркированные (по ключевым понятиям и/или пословичным образам).

Ключевые слова: лексикография; паремиология; пословица; структурно-семантическая модель; полилингвальный словарь; тувинский язык; тувинский фольклор; современный европейский язык

Публикация выполнена при поддержке Программы стратегического академического лидерства РУдН и при финансовой поддержке Российского научного фонда в рамках научного проекта «Тезаурус этнической культуры в XXI веке: проблемы исследования и сохранения (на примере тувинской культуры)» (грант № 21-18-00246).

Для цитирования:

Бредис М. А., Иванов Е. Е., Ломакина О. В., Нелюбова Н. Ю., Кужугет Ш. Ю. Лексикографическое описание тувинских пословиц: принципы, структура, этнолингвокультурологический комментарий (на европейском паремиологическом фоне) // Новые исследования Тувы. 2021, № 4. С. 143-160. DOI: https://www.doi.org/10.25178/nit.2021.4.11

Бредис Михаил Алексеевич - кандидат филологических наук, ведущий научный сотрудник кафедры иностранных языков филологического факультета Российского университета дружбы народов. Адрес: 117198, Россия, г. Москва, ул. Миклухо-Маклая, д. 6. Тел.: +7 (910) 462-95-62. Эл. адрес: bredis-ma@rudn.ru

Иванов Евгений Евгеньевич - кандидат филологических наук, доцент, заведующий кафедрой теоретической и прикладной лингвистики факультета иностранных языков Могилёвского государственного университета имени А.А. Кулешова. Адрес: 212022, Беларусь, г. Могилёв, ул. Космонавтов, д. 1. Тел.: +375 (29) 691-50-01. Эл. адреc: ivanov_ee@msu.by

Ломакина Ольга Валентиновна - доктор филологических наук, профессор кафедры русского языка Института филологии Московского педагогического государственного университета; профессор кафедры иностранных языков филологического факультета Российского университета дружбы народов. Адрес: 119991, Россия, г. Москва, ул. Малая Пироговская, д. 1; 117198, Россия, г. Москва, ул. Миклухо-Маклая, д. 6. Тел.: +7 (967) 118-71-45. Эл. адрес: lomakina-ov@rudn.ru

Нелюбова Наталия Юрьевна - кандидат филологических наук, доцент, доцент кафедры иностранных языков филологического факультета Российского университета дружбы народов. Адрес: 117198, Россия, г. Москва, ул. Миклухо-Маклая, д. 6. Тел.: +7 (926) 532-15-77. Эл. адрес: nat.nelubova@mail.ru

Кужугет Шенне Юрьевна - кандидат филологических наук, заведующая кафедрой педагогики и методики дошкольного и начального образования, старший научный сотрудник лаборатории этнологии и лингвокультурологии Тувинского государственного университета. Адрес: 667000, Россия, г. Кызыл, ул. Ленина, д. 36. Тел.: +7(923)388-69-99. Эл. Адрес: kuzhuget-sh@mail.ru 


\title{
A lexicographical description of Tuvan proverbs: Principles, structure and an ethnolinguoculturological commentary as compared to European paremies
}

\author{
Mikhail A. Bredis \\ RUDN University, Russian Federation, \\ Eugene Eu. Ivanov \\ A.A. Kuleshov Mogilev State University, Republic of Belarus, \\ Olga V. Lomakina \\ Moscow Pedagogical State University; RUDN University, Russian Federation, \\ Natalia Yu. Nelyubova \\ RUDN University, Russian Federation, \\ Shenne Yu. Kuzhuget \\ Tuvan State University, Russian Federation
}

Due to the absence of a typological description of Tuvan proverbs, the Tuvan proverb corpus seems to appear in an artificial isolation. On the contrary, it must be seen for what it is - an organic part of the Eurasian paremiological continuum. This part has both proverbs it shares with other languages and unique ones which mark the ethnocultural distinctiveness of the Tuvan people. It is thus of utter importance (and ultimate difficulty) that a lexicographical description of Tuvan proverbs must be built with paremiology of European language as its background.

The aim of this study is to lay a methodological foundation for a description of Tuvan proverb corpus compared against European proverbs - a foundation which should cover its principles, structure and ethnolinguocultural commentary.

Looking for factual material, we turn to editions of collections of Tuvan proverbs and sayings, to dictionaries, including the most authoritative paremiological dictionaries of modern European languages, such as the ones edited by E. Strauss, G. Paczolay, K. Grigas, V. M. Mokienko, or M. Yu. Kotova.

The description, as well as its principles, is based on the theory of structural semantic modeling, which, in its turn, suggests that each unit of the corpus of Tuvan proverbs should be subjected to a differentianting use of the generality/specificity criterion. Compared against European counterparts, each Tuvan proverb can be seen as fully vs. partly analogous and absolutely vs. correlatively unique (in accordance with the structural semiotic model), the partly analogous further subdivided into ethnolinguistically vs. ethnoculturally assimilated, and the correlatively unique into ethnolinguistically vs. ethnoculturally marked (by key ideas and/or proverbial imagery).

Keywords: lexicography; paremiology; proverb; structural semantic model; multilingual dictionary; Tuvan language; Tuvan folklore; modern European language

The publication was supported by the Program of strategic academic leadership, RUDN University, and with financial support from the Russian Science Foundation, project "Thesaurus of an ethnic culture in the 21st century: research and preservation (the case of Tuvan culture)", grant No. 21-18-00246.

\footnotetext{
For citation:

Bredis M. A., Ivanov Eu. Eu., Lomakina O. V., Nelyubova N. Yu. and Kuzhuget Sh. Yu. Leksikograficheskoe opisanie tuvinskikh poslovits: printsipy, struktura, etnolingvokul'turologicheskii kommentarii (na evropeiskom paremiologicheskom fone) [A lexicographical description of Tuvan proverbs: Principles, structure and an ethnolinguoculturological commentary as compared to European paremies]. New Research of Tuva, 2021, no. 4, pp. 143-160. (In Russ.). DOI: https://www.doi.org/10.25178/ nit.2021.4.11
}

BREDIS, Mikhail Alekseyevich, Candidate of Philology, Leading Research Fellow, Department of Foreign Languages, Faculty of Philology, RUDN University. Postal address: 6 Miklouho-Maclay St., 117198 Moscow, Russian Federation. Tel.: +7 (910) 462-95-62. Email: bredis-ma@rudn.ru ORCID ID: 0000-0003-4885-952X

IVANOV, Eugene Euvgenevich, Candidate of Philology, Associate Professor and Head, Department of Theoretical and Applied Linguistics, Faculty of Foreign Language, A. A. Kuleshov Mogilev State University. Postal address 1 Kosmonavtov St., 212022 Mogilev, Republic of Belarus. Tel.: +375 (29) 691-50-01.Email: ivanov_ee@msu.by ORCID ID: 0000-0002-6451-8111 LOMAKINA, Olga Valentinovna, Doctor of Philology, Professor, Department of Russian, Institute of Philology, Moscow Pedagogical State University; Professor, Department of Foreign Languages, Faculty of Philology, RUDN University. Postal address: 1 Malaya Pirogovskaya St., 119991 Moscow; 6 Miklouho-Maclay St., 117198 Moscow, Russian Federation. Tel.: +7 (967) 118-71-45.Email: : rusoturisto07@mail.ru; lomakina-ov@rudn.ru ORCID ID: 0000-0003-0298-5678 NELYUBOVA, Natalia Yurievna, Candidate of Philology, Associate Professor, Department of Foreign Languages, Faculty of Philology, RUDN University. Postal address: 6 Miklouho-Maclay St., 117198 Moscow, Russian Federation. Tel.: +7 (926) 532-15-77. Email: nat. nelubova@mail.ru ORCID ID: 0000-0002-6538-8267

KUZHUGET, Shenne Yurievna, Candidate of Philology, Senior Research Fellow, Laboratory of Ethnology and Linguoculturology, Head, Department of Pedagogics and Methodology of Pre-School and Primary Education; Tuvan State University. Postal address: 36 Lenina St., 667000 Kyzyl, Russian Federation. Tel.: +7(923)388-69-99. Email: kuzhuget-sh@mail.ru ORCID ID: 0000-0002-3507-3053 


\section{Введение}

Тувинская паремиография на сегодняшний день представлена десятком различных по объёму и языку (оригинальных, с переводами или только переводные на русский язык) сборников тувинских пословиц и поговорок, из которых наиболее популярным до совсем недавнего времени было издание 1966 г., подготовленное М. А. Хадаханэ и О. К. Саган-оолом ${ }^{1}$, и впоследствии несколько раз переизданное. В 2003 г. появился сборник Б. К. Будупа, выдержавший несколько стереотипных изданий (последнее в 2020 г. $^{2}$ ), однако содержащий множество неточных переводов тувинских пословиц на русский язык. Все издания тувинского пословичного фонда представляют собой фольклорные сборники, в них пословицы подаются как фразовые тексты (произведения малых жанров устного народного творчества), а не как языковые единицы, функционирующие в устной и письменной речи, которые имеют формальные варианты, значение и его экспрессивные коннотации в различных ситуациях, связаны между собой (и с другими единицами языка) разными семантическими и деривационными отношениями. Авторы-составители сборников тувинского пословичного фонда не ставили целью его языковедческое описание, на первом плане была популяризация фольклора, поэтому пословицы издавались с литературными переводами на русский язык, содержащими неточности, и не сопровождались научными комментариями.

Тувинские пословицы, как и пословицы любого языка, соотносятся с иноязычными пословицами, имеют межъязыковые аналоги или эквиваленты, восходят по своему происхождению к другим языкам - являются кальками или заимствованиями, характеризуются в межъязыковом плане специфичностью, интернациональностью, универсальностью. Исследование связей пословичных фондов тувинского народа и других народов мира существенно затрудняет отсутствие сопоставительного словаря тувинских и иноязычных пословиц.

Актуальными задачами тувинской паремиологии на современном этапе её развития, на наш взгляд, являются разработка принципов лингвистического описания пословиц в паремиологических словарях - нормативном (толковом), переводном (двуязычном), сопоставительном (на фоне родственных, ареально близких, типологически значимых языков), лингводидактическом (школьном) и др. Наибольший интерес (и наибольшую трудность) представляет в этой связи разработка сопоставительного словаря тувинских и европейских пословиц, который позволит преодолеть изолированность тувинского пословичного фонда, входящего в евразийский паремиологический континуум, от широкого сравнительного и типологического изучения пословиц европейских и азиатских народов.

Цель исследования - разработать принципы, обосновать структуру и определить этнолингвокультурологическое содержание лексикографического описания тувинских пословиц, при котором они будут последовательно сопоставлены с пословицами современных европейских языков на уровне структурно-семантических моделей, ключевых понятий и пословичных образов.

Фактическим материалом для исследования послужили 770 тувинских пословиц ${ }^{3}$, а также 7500 пословиц из 20 европейских языков, отобранных из авторской картотеки, полученной путём сплошной выборки из авторитетных паремиографических источников современных европейских языков (Grigas, 1987; Strauss, 1994; Рaczolay, 1997; Котова, 2000; Muñoz, 2001; Мокиенко, Никитина, Николаева, 2010; Петрушэўская, 2020).

Методологической основой исследования послужило современное понимание паремиологии как самостоятельного направления в языкознании (Паремиология в дискурсе, 2015; Паремиология без границ, 2020), а также основные положения теории пословицы как явления языка (Бредис, Ломакина, Мокиенко, 2019; Бредис, Димогло, Ломакина, 2020) и как афористической единицы (Иванов, 2009; Иванов, 2019ab; Иванов, 2020), структурно-семантического моделирования пословиц (Ivanov, Feld-

\footnotetext{
${ }^{1}$ Тувинские пословицы и поговорки / сост.-пер. М. Хадаханэ, О. Саган-оол. Кызыл : Тувкнигоиздат, 1966.172 с. (На рус. и тув. яз.).

2 Пословицы и поговорки тувинского народа / авт.-сост. Б. К. Будуп. Кызыл : Тувинское книжное издательство; Радуга Тувы, 2020. 112 с. (На рус. и тув. яз.).

${ }^{3}$ Пословицы отобраны методом фронтальной выборки из хронологически самого новейшего сборника: Пословицы и поговорки тувинского народа / авт.-сост. Б. К. Будуп. Кызыл: Тувинское книжное издательство; Радуга Тувы, 2020. 112 с. Помимо этого при анализе учитывались материалы изданий: Мудрость народа. Тувинские пословицы и поговорки / сост. М. Хадаханэ, О. Саган-оол. Кызыл : Тувкнигоиздат, 1976. 78 с. (На тув. и рус. яз.); а также (Тувинско-русский ..., 1968, 2004).
} 
man, 2007; Петрушэўская, 2020; Іваноў, Петрушэўская, 2021) и их лингвоаксиологической интерпретации (Ломакина, Мокиенко, 2018; Нелюбова, 2019; Нелюбова, Хильтбруннер, Ершов, 2019; Нелюбова, Сёмина, Казлаускене, 2020), культурно-языкового трансфера пословиц (Ломакина, Мокиенко, 2016; Бредис, Ломакина, Мокиенко, 2020; Lomakina, 2021) и их этимологического анализа (Ivanov, Petrushevskaia, 2015).

Анализ национально-культурной специфики тувинских пословиц, их связей с пословицами и поговорками других народов базируется на основных дескриптивных и сопоставительных, лингвокультурологических исследованиях пословично-поговорочного фонда тувинского народа (Доржу, 2012; Чадамба, 2014; Коняшкин, Чадамба, 2014ab; Чадамба, 2015; Кечил-оол, Саая, 2016, 2017; Болатоол, Пелевина, 2017; Коняшкин, Чадамба, 2017; Салчак, 2019; Чугунекова, 2019; Егорова, Кондакова, Кужугет, 2020; Иванов, Ломакина, Нелюбова, 2021), а также на широком историко-этнографическом описании тувинского фольклора (Курбатский, 2001; Бурыкин, Болдырева, Музраева, 2019), изучении материальных и духовных особенностей тувинской культуры (Ламажаа, 2015; Будегечиева, 2018).

\section{Зоны лексикографического описания}

Лексикографическое описание тувинских пословиц на фоне европейских в полилингвальном словаре с этнолингвокультурологическим комментарием предполагает специальную разработку комплекса зон словарной статьи, не имеющего аналогов в паремиографии. Обозначенный комплекс должен включать как традиционные, так и специфические зоны с учётом той лексикографической информации, которая должна быть представлена в данном типе словаря.

Наиболее лексикографически значимой информацией в этом случае являются, во-первых, имеющиеся формальные варианты тувинской пословицы, во-вторых, аутентичный перевод тувинской пословицы на языки различной грамматической структуры, в-третьих, наличие и объём аналогов и коррелятов тувинской пословицы в европейских языках, в-четвёртых, дифференциация общности / специфичности тувинских и европейских пословиц на уровне структурно-семантических моделей, ключевых понятий, пословичных образов, в-пятых, этнолингвокультурная специфика тувинских аналогов и коррелятов европейским пословицам, в-шестых, семантические парадигматические связи в тувинском пословичном фонде.

Основными зонами сопоставительного этнолингвокультурологического описания тувинских пословиц на европейском паремиологическом фоне в полилингвальном словаре, исходя из репрезентации указанных выше 6 типов лексикографически значимой информации, целесообразно считать следующие: 1) зона реестровой единицы (1 и 2 типы); 2) зона иноязычного аналога или коррелята (3 тип); 3) зона этнолингвокультурологического комментария (4 и 5 типы); 4) зона парадигматических связей пословиц в тувинском языке (6 тип).

Зона реестровой единицы включает в себя тувинскую пословицу (с указанием всех имеющихся её формальных вариантов), аутентичный перевод тувинской пословицы на русский и английский языки, указание на наличие общности / специфичности тувинской пословицы с пословицами современных европейских языков.

Формальные варианты пословицы позволяют максимально адекватно и полно репрезентировать её в качестве реестровой единицы лингвистического паремиологического словаря. Под формальными вариантами следует понимать такие вариации лексико-грамматической организации пословицы, которые объединены одним общим значением, однако могут отличаться внутренней формой (включать разные пословичные образы и/или ключевые понятия). Так, формальными вариантами одной пословицы являются Кортук кижиниң кулаа дыыжы (с. 34¹), Кортук кижиниң караа көскү (с. 109) 'У трусливого глаза зорки', Хоюган абттың караа көскү, кортук кижиниң кулаа дыыжы (с. 59) 'У пугливого коня глаза зорки, а трусливого человека - острый слух', поскольку все они имеют общее значение 'Кто труслив, тому везде и во всём мерещится опасность', хотя и различаются ключевыми понятиями (кортук кижи 'трусливый человек' / хоюган ағт 'пугливый конь') и пословичными образами (кулаа дыыжы 'уши остры' / караа көскү 'глаза зорки’). То же справедливо и в отношении Өжээн кырывас (с. 44) ‘Месть не стареет’ и Назын кырыыр, өжээн кырывас (с. 41) ‘букв. Возраст стареет, а месть не стареет’,

${ }^{1}$ Здесь и далее указываются страницы по изданию: Пословицы и поговорки тувинского народа / авт.-сост. Б. К. Будуп. Кызыл: Тувинское книжное издательство; Радуга Тувы, 2020. 112 с. 
где один из вариантов включает факультативный пословичный образ (өжээн кырывас 'месть не стареет’). Или также Сөөк чугазы сыйлыычал (с. 50) ‘букв. Тонкая часть кости хрупкая’ и Алгы чугазы ойлур, сөөк чугазы сыйлыр (с. 15) ‘Тонкая шкура продырявится, тонкая часть кости хрупкая’, где в одном из вариантов используется факультативный пословичный образ (алгы ойлур 'шкура становиться дырявой'). То же для Оол аътка ынак (с. 42) 'мальчики любят лошадей’ и Кыс этке ынак, оол аътка ынак (с. 38) 'Девочки любят вещи, а мальчики лошадей’, где один из вариантов включает факультативную предикативную часть (Кыс этке ынак 'Девочки любят вещи'). Встречаются варианты инверсирования предикативных частей, напр.: Даг аътылы човадыр, кылык ботту човадыр (с. 23) 'Гора коня измучает, норов - человека’ и Кылык ботту човадыр, даг аътты човадыр (с. 37) 'Норов измучает человека, гора коня’. Нередка вариантность лексического состава и грамматической организации пословицы, напр.: Кижи чугаалажып таныжар, аът киштежип таныжар (с. 33) 'Люди знакомятся в разговоре, лошади во время ржания’ и Мал киштежип таныжар, чон чугаалажып таныжар (с. 40) ‘Лошади знакомятся во время ржания, народ - в разговоре'.

Фиксация формальных вариантов пословицы позволяет адекватно реконструировать её структурно-семантическую модель (Іваноў, Петрушэўская, 2021: 107-108; Иванов, Ломакина, Нелюбова, 2021 : 223-225), что является необходимым условием не только для лексикографического описания, но и для типологического и лингвокультурологического сравнения тувинских пословиц на фоне других языков.

Аутентичный перевод тувинской пословицы на русский и английский языки позволяет использовать его в качестве Tertium comparationis (третьего члена сравнения), необходимого для верифицируемого установления в иных языках пословиц, тождественных или близких по структурно-семантической модели тувинской пословице (т. е. её межъязыковых пословичных аналогов и коррелятов). Так, пословица Тенек баш бут човадыр обычно переводится как 'Дурная голова ногам покоя не даёт' (с. 51), что соответствует = рус. Дурная голова ногам покою не даёт и даёт возможность установить её аналоги в восточнославянских языках = бел. За дурной галавой $i$ нагам неспакой; За дурною галавою $i$ нагам спакою няма = укр. За дурною / пустою головою нема ногам спокою (Котова, 2000: 41). Более точный (аутентичный) перевод этой пословицы - ‘Дурная голова ноги изнуряет’, отмеченный в нашей статье (Иванов, Ломакина, Нелюбова, 2021: 225), позволяет рассматривать её на гораздо более широком языковом фоне как аналог в тувинском языке универсальной пословичной структурно-семантической модели A stupid head makes much work to the feet (v2) (Paczolay, 1997: 280), которая реализуется в разных европейских языках = чеш. Zle nohám pod bláznovskou hlavou = лит. Durna galva - kojoms klapatas $/$ vargas = англ. A witless head makes a weary pair of heels = нем. Was der Kopf vergisst, müssen die Füsse entgelten = фин. Tyhmän pään takii kärsii koko ruumis - Из-за глупой головы страдает всё тело (там же: 280-281).

Точность перевода тувинских пословиц представляет собой актуальную проблему, о которой не раз писали исследователи, в том числе на материале художественных текстов на русском языке (Коняшкин, Чадамба, 2014ab, 2017; Чадамба, 2014, 2015), однако не рассматривалась, как и особенности перевода на английский язык, в лексикографическом аспекте. Аутентичность перевода, помимо своей роли для межъязыкового сопоставления, является важнейшим компонентом словарной репрезентации формы и содержания пословиц в лингвистическом паремиологическом словаре. Поэтому проблема достижения аутентичности при переводе тувинских пословиц на языки различного грамматического строя требует специального глубокого изучения.

Проблема аутентичных переводов стала очевидной для нас в ходе нашей работы с двуязычными изданиями тувинских пословиц, в которых присутствуют разные способы перевода и соответствующие им ошибки, неточности и искажения; иногда встречаются и варианты безэквивалентной лексики. В случае художественных, «поэтических» переводов - они были заменены нами на дословные.

Указание в зоне реестровой единицы на наличие общности (близости) / специфичности структурносемантической модели, полной / частичной аналогии, абсолютной / коррелятивной уникальности ключевых понятий и/или пословичных образов тувинской пословицы в сопоставлении с пословицами современных европейских языков (балтийских, германских, романских, славянских) манифестирует наличие, содержание и объём зоны иноязычного аналога или коррелята.

Зона иноязычного аналога или коррелята актуализируется в случае наличия у реестровой единицы общности или близости с европейскими паремиями и включает в себя иноязычную пословицу как аналогичную или коррелятивную (близкую) тувинской пословице по структурно-семантической модели, ключевым понятиям, пословичным образам, а также указание на характер аналогии или корреляции - универсальный, интернациональный, этнонациональный (Петрушевская, 2021). В слу- 
чае обнаружения абсолютной уникальности тувинской пословицы по структурно-семантической модели, ключевым понятиям и пословичным образам (на европейском языковом фоне) зона иноязычного аналога или коррелята не актуализируется при её словарном описании (пословичные аналоги или корреляты в современных европейских языках отсутствуют).

Так, пословица Балык бажындан чыдыыр, терек өзээнден ириир (с. 20) 'Рыба сгниет с головы, дерево становится трухлявым изнутри’ имеет соответствия в тех европейских языках, которые не контактировали с тувинским языком, а значит, является вариантом универсальной пословицы со структурно-семантической моделью Fish always begin,-s to stink / decay at the head (or stink,-s first at the head) (Paczolay, 1997: 440), ср.: = бел. Рыба з галавы гніе (загніваецца, пачынае гніць, псуецца); Рыба 3 галавы гніе (загніваецца, псуецца) = болг. Рибата от главата вонее (се / са ввонява / всмбрдява) = польск. Ryba psuje się (cuchnie) od głowy; Od głowy ryba śmierdzi = рус. Рыба с головы гниёт (воняет, тухнет); Рыба гниёт (загнивает, портиться, тухнет) всегда с головы = словац. Od hlavy ryba smrdí = словен. Iz glave riba smrdi = укр. Риба від голови смердит; Від голови риба починає смердіть = чеш. Od hlavy ryba smrdí = лат. Zivs sāk püt no galvas = лит. Žuvis nuo galvos pradeda dvokti = англ. Fish begins to stink at the head = нем. Der Fisch fängt am Kopf an zu stinken; Der Fisch stinkt am Kopf zuerst = исп. El pez, por la cabeza hiede = ит. Il pesce comincia a puzzare dal capo (dalla testa); Il pesce comincia / incomincia a putir / puzzar dal capo = фp. Le poisson commence toujours à sentir par la tête = венг. A hal is a fejétöl büdösödik; Fej(é)től búzlik / büdösödik a hal (Strauss, 1994a: 996; Paczolay, 1997: 440-442; Котова, 2000: 133; Петрушэўская, 2020: 89).

Вместе с тем тувинская пословица Балык бажындан чыдыыр, терек өзээнден ириир (с. 20) полностью аналогична иноязычным пословицам только первой частью своей структурно-семантической модели (Балык бажындан чыдыыр), тогда как вторая её часть (Терек өзээнден ириир) специфична по отношению к европейскому паремиологическому фону. Однако специфичность этой тувинской пословицы как этнонационального варианта универсальной пословицы Fish always begin,-s to stink / decay at the head (or stink,-s first at the head) (Рaczolay, 1997: 440) требует параллельной верификации на азиатском пословичном материале. Следует заметить, что двухкомпонентные варианты этой универсальной пословицы встречаются не только в тувинском языке, но и в других языках самых разных языковых семей, напр.: = рус. Рыба от головы тухнет, а дурак - от ума (Мокиенко, Никитина, Николаева, 2010: $776)$ = бурят. Загаһан толгойһо гутаха, залхуу табгайһаан гутаха 'Рыба гниёт с головы, лентяй с ноги' ${ }^{1}$. В татарском языке есть полный аналог тувинской пословицы о тухлой рыбе и гнилом тополе, ср.: = Балык - башыннан, тирәк үздгеннән чери 'Рыба с головы, тополь - с сердцевины гниёт' (Татарские народные ..., 2020: 94), при этом татарская пословица имеет формальный вариант со славянским тополь, ср.: = Балык - башыннан, тополь ұздгеннән чери (Галиуллин, 2018: 362). Специфичность второй части тувинского этнонационального варианта универсальной пословицы на фоне европейских языков и её межъязыковая общность на азиатском паремиологическом фоне требует включения в словарь соответствующего этнолингвокультурологического комментария.

Кроме полных или частичных аналогов по структурно-семантической модели, тувинские пословицы могут иметь в европейских языках непереводные пословичные корреляты - такие иноязычные пословицы, которые не совпадают с тувинскими по структурно-семантической модели, но имеют полностью или частично коррелятивные в них ключевые понятия и/или пословичные образы. Так, в тувинских и европейских пословицах можно выделить аналогичные ключевые понятия (общие социокультурные, аксиологические, эмпирические концепты и / или когнитемы: ажыл / аъш-чем = англ. work / eat, ит. lavoro / mangiare, нем. arbeitet / essen и др.; бай / ядыь = лит. bagotas / biednas, польск. bogaty / biedny и др.), тождественную образность (общие и близкие пословичные образы: куш / уя = англ. bird / nest, фр. oiseau / nid, чеш. ptačí / hnízdo и др.; бөру (кокай) / хой = польск. wilk / оwса; бел. воўк / авечка и др.).

Например, пословицы из состава национально-культурного компонента паремиологического фонда белорусского языка - Баязліўу і заяц воўк (Іванова, Іваноў, 1997: 42), русского языка - Трусливому зайке и пенёк волк (Мокиенко, Никитина, Николаева, 2010: 359) не имеют структурно-семантических аналогов в тувинском языке, однако коррелируют с теми тувинскими пословицами, в которых используются образы «бөру / кокай» ('волк') и «кодан / койгун» (‘заяц’). Показательно, что в тувинских пословицах данные образы никогда не используются как «пословичный бином» (Селиверстова

${ }^{1}$ Оньһон үгэ (3) пословицы и поговорки [Электронный ресурс] // Уран хун. 2019, 13 августа. URL: uran-media.ru/ nasledie/onhon-gje-z-poslovicy-i-pogovorki-na-bukvu-z/ (дата обращения: 16.08.2021). 
2009), обусловлены иными аксиологемами, встроены в иные социокультурные контексты, однако могут иметь тождественную внутреннюю форму (обусловлены одинаковыми когнитемами), напр.: Бөрү кырыза-даа, дижи чидиг ‘букв. Даже если волк стареет, зубы останутся острыми'; Бөрүлүг ойну хой эндевес (с. 93) ‘букв. Овцы издалека чувствуют низину с волками’; Кокайга хой кадартпа, хопчуга сөс дыңнатпа (с. 34) ‘букв. Волку не давай овец пасти, слово не сообщи клеветнику’; Кокпага киргенде, койгун чүгүрүк, коданга киргенде, ыт эрги (с. 34) ‘букв. Быстро скачет заяц при звериной тропе, собаки громко лают поблизости аала’ и др. Понятийные и образные корреляты в тувинских и европейских пословицах должны сопровождаться указанием на природу их общности / близости / специфичности, обеспечиваться соответствующим этнолингвокультурологическим комментарием.

Зона этнолингвокультурологического комментария аккумулирует разного рода толкования этнолингво- / этнокультурно ассимилированных или этнолингво- / этнокультурно маркированных на уровне ключевых понятий и пословичных образов тувинских пословиц, имеющих пословичные аналоги или корреляты в современных европейских языках.

Содержание и структура этнолингвокультурологического комментария пословиц в словарях различных типов не имеет в современной паремиологии однозначного понимания, поэтому требует специальной разработки. Такой комментарий может включать информацию лингвокультурологического, этнолингвистического, лингвоаксиологического характера, направленную на описание структурно-семантической модели, репертуара ключевых понятий и пословичных образов; особенностей этнолингво- / этнокультурной ассимиляции / корреляции тувинской пословицы в последовательной сопоставительной проекции на аналогичные или близкие по данным параметрам (коррелятивные) европейские пословицы.

Содержание этнолингвокультурного комментария тувинских пословиц с учётом их дифференциации на имеющие / не имеющие общие структурно-семантические модели с пословицами в современных европейских языках более подробно рассматривается в отдельных двух разделах данной статьи (см. ниже).

Зона парадигматических связей в тувинском языке предназначена отражать синонимы, антонимы реестровой единицы, близкие ей по структурно-семантической модели, ключевым понятиям, пословичным образам тувинские пословицы.

Например, пословица Кортуктуң чүрээ аксында, хоюганның кулаа кудуруунда 'Сердце у труса во рту стучит, у пугливого уши у хвоста’ (с. 109) является синонимичной пословице, имеющей ряд формальных вариантов: Кортук кижиниң кулаа дыыжы 'У трусливого человека уши остры' (с. 34), или Кортук кижиниң караа көскү 'У трусливого человека глаза зорки' (с. 109), или Хоюган аъттың караа көскү, кортук кижиниң кулаа дыьжы (с. 59) 'У пугливого коня глаза зорки, а трусливого человека - острый слух’.

Пословицы Харам кижиниң караа соок 'У скупого глаза холодные' (с. 57) и Кортук кижиниң караа көскү (с. 109) ‘У трусливого глаза зорки’ имеют весьма близкую структурно-семантическую модель с одинаковыми компонентами кижи 'человек’ и караа 'глаза', но различаются ключевыми понятиями харам 'жадный’ / кортук 'трусливый’ и пословичными образами соок 'холодный’ и көскү 'зоркий, видный, что указывает на многообразие аксиологических интерпретаций качеств человека и их предметного осмысления и переосмысления в тувинской пословичной картине мира.

Пословицы Хүннээчелдиң караа көскү 'У ревнивца глаза зорки’ (с. 61) и Кортук кижиниң караа көскү 'У трусливого глаза зорки' (с. 109) также весьма близки по структурно-семантическим моделям, имеют одинаковые компоненты караа көскү, которые не только образуют устойчивую ассоциативную связь между двумя этими пословицами, но и обусловливают одинаковое отношение к понятиям 'ревнивец' и 'трус' в ценностной иерархии восприятия тувинцами личностных качеств человека.

Пословицы Өшкенден чылыг эреве, өлгенден чем эреве 'Не грейся у потухшего огня, не надейся на мёртвого' (с. 46) и Өшкен оът кывар, өлген кижи турбас 'Огонь угасший разгорится, умершему не возвратиться’ (с. 46) ассоциативно связаны, поскольку имеют одинаковую пословичную образность («потухший / угасший огонь») и одно и то же ключевое понятие («мёртвый / умерший человек»), манифестирующие связь огня и смерти в традиционной (пословичной) этнонациональной картине мира тувинского народа.

Репрезентация парадигматических связей пословиц в тувинском языке имеет важное значение для выявления, дифференциации и установления взаимоотношений типологически общих (близких) 
с европейскими языками и этнокультурно обусловленных (маркированных) единиц в составе тувинского пословичного фонда.

\section{Этнолингвокультурологический комментарий тувинских пословиц, которые имеют пословичные аналоги в европейских языках}

Этнолингвокультурологический комментарий тех тувинских пословиц, которые аналогичны по структурно-семантической модели европейским пословицам, но отличаются национально-языковым и /или этнокультурным своеобразием на уровне когнитивных компонентов плана содержания и / или образной структуры, целесообразно основывать на синхронической проекции этнонациональной тувинской картины мира на исторически сложившуюся современную полинациональную картину мира европейцев. При этом важно учитывать факты специфичности тувинской пословичной картины мира по отношению к пословичной картине мира каждого европейского народа по отдельности.

Так, тувинская пословица Кортук кижиниң караа көскү (с. 109) 'У трусливого человека глаза зоркие' отличается от своих европейских аналогов = англ. Fear has magnifying eyes = лат. Bailēm lielas acis $=$ лит. Baime turi dideles akis = нем. Furcht hat große Augen = польск. Strach ma wielkie oczy = pyc. У страха глаза велики = укр. Страх має великі очі = фр. La peur a de grands уеих (Петрушэўская, 2020: 282) ключевыми понятиями кортук кижиниң, караа, а также образным компонентом көскү, указывающим на приоритет в тувинской картине мира социально важной характеристики концепта глаза - зоркие, в отличие от общеевропейского социально нейтрального соматического образа глаза - больщие, что исторически обусловлено традиционным образом жизни тувинского народа, занимавшегося кочевым скотоводством, когда наибольшую значимость имели не статичные (внешние), а функциональные (внутренние) качества физических параметров человека.

Тувинская пословица Бодунуң бажында теве көрбейн, эжиниң бажында тевене көрген (с. 21) 'У себя на голове верблюда не разглядел, у товарища на голове иголку заметил’ отличается национальноспецифичной образностью от своих аналогов в европейских языках, ср.: = англ. You can see a mote in another's eye but cannot see a beam on your own = рус. В чужом глазу сучок / соломинку видим, в своем бревна не замечаем = фр. On voit une paille dans l'oeil de son prochain/voisin et pas une poutre/bûche dans le sien = исп. En el ojo de su vecina ve una paja y en el suyo no ve una viga/trance = итал. Si vede la paglia / scheggia nell'occhio altrui e non si vede la trave nel proprio и др. (Раczolay, 1997: 131-136). Эта интернациональная пословица имеет библейское происхождение (Лепта библейской мудрости ... 2019b: 149-152) и в европейских языках сохраняет евангельскую образность «сучок / соломинка» и «бревно» (Мф 7, 3-5; Лк 6, 41), хотя первый компонент данного двучленного образа может варьироваться, что отражено в структурно-семантической модели европейской пословицы, ср.: You see the mote / hair / needle / shaving / splinter / straw / twiglet in another's (or in your brother's) eye but fail to see the beam in your own (Paczolay, 1997: 131). В тувинской пословице представлены неожиданные, на первый взгляд, образы «иголка» и «верблюд», которые, однако, появились в ней вовсе не случайно. Во-первых, зооним верблюд широко используется в тувинских пословицах, напр.: Демниг сааскан теве тудуп чиир (с. 25) 'Дружные сороки верблюда съедают’; Кертик-ле чүве теве эвес, кемниг (четпес, багай, буруулуг)-ле чүве мен эвес (с. 32) 'Не каждый верблюд с зарубкой, не каждый человек с дефектом’; Көшкенде, теве херекчок, кешкенде, хеме херекчок (с. 35) 'После кочевки верблюд не нужен, после переправы лодка не нужна'; Сөөлгү тевениң чүбгү аар (с. 49) 'У последнего верблюда груз тяжелый’; Хаак баштаан тевени өщкү кайгаар, хая кырлаан өшкүнү теве кайгаар (с. 56) 'Верблюда за тальником присматривает коза, козу за скалой присматривает верблюд’; Чыткан теве аксынга каңммы кирген (с. 70) ‘В рот лежащего верблюда попало перекати-поле’ (Тувинско-русский ..., 2014: 225) и др., что объясняется ролью верблюда в традиционном укладе жизни кочевого народа. Во-вторых, выбор данной пары образов в тувинской пословице детерминирован и созвучной фонетической формой слов теве ('верблюд’) и тевене ('игла’). В-третьих, в образном противопоставлении, использованном в тувинской пословице, важен контраст в размерах верблюда и иглы, что способствует большей экспрессии в передаче пословичного смысла по сравнению с противопоставлением «сучок / соломинка» vs. «бревно». Не случайно контрастный бином «верблюд» vs. «игла» используется ещё в одном широко распространённом в европейских языках библейском обороте Легче верблюду пройти сквозь игольное ушко, чем..., поскольку «игла»в общепринятом понимании является эквивалентом малого, а «верблюд» у многих народов Азии является «мерилом большой величины» (Лепта библейской мудрости ..., 2019а: 59). Именно азиатское влияние детерминировало этнокультурную ассимиляцию в тувинском языке интернациональной пословицы евангельского 
происхождения в результате замены аксиологически нейтрального европейского тяжёлого «бревна» на имеющего значительную ценность в азиатском мире большого «верблюда» (и, соответственно, лёгкой, но бесполезной «соломинки» на маленькую, но всегда нужную «иглу»).

Ещё одна тувинская пословица, в которой используется образ «верблюд», Чыткан теве аксынга каңмыыл кирген (с. 70) ‘В рот лежачего верблюда перекати-поле попало’ является этноспецифическим вариантом универсальной пословицы со структурно-семантической моделью Roast pigeon / lark / sparrow / goose / chicken / hen / bird / does not fly into one's mouth (v1) or He expects roast pigeons etc. to fly into his mouth (v2) or A sleeping fox / wolf catches no hen / hare / sheep (catches nothing) or No sheep will run into the mouth of a sleeping wolf (v3) (Раczolay, 1997: 455), где, кроме гастрономического кода, реализуется и зоонимический код культуры, ср.: = англ. The sleeping fox cathches no poultry = рус. Спящему коту мышь в рот не прибежит = ит. Volpe che dorme, vive sempre magra = исп. A la vulpeja dormida, no le cae nada en la boca = фр. A renard endormi rien ne tombe dans la gueule (там же: 455-458). Во всех европейских пословицах пассивность обозначается образными компонентами «спящий» / «лежащий» для выражения общего смысла 'Невозможно ничего получить, не приложив труда, усилий'. Однако в тувинской пословице всё наоборот: 'Не прилагая усилий, можно получить минимально необходимое' (т. е. выпала удача без труда), поскольку верблюд в ней используется как мерило неприхотливости (это животное может питаться любой растительностью, в том числе «перекати-поле» - травянистым растением, которое после отмирания образует лёгкие сухие круглые либо овальные клубки, перекатывающиеся по степи ветром). «Лежащий верблюд» в тувинской пословице означает не пассивность, а неторопливость, умение терпеть, ждать своего часа (утомительно ловить в голой зимней степи перекати-поле, лучше подождать, пока ветер прикатит его прямо под ноги), что существенно расширяет структурносемантическую модель данной универсальной пословицы (тувинская пословица образует в её составе отдельный, уникальный этнонациональный вариант).

Одной из тувинских пословиц, имеющих аналоги в европейских языках, является Даартагы чагдан бөгүнгү өкпе дээре - Завтрашнего сала сегодняшние лёгкие лучше (с. 23), которая является вариантом универсальной пословицы со структурно-семантической моделью Better one bird / pigeon / sparrow / in the hand / plate than two / ten / hundred in the air [or on the branch / fence / roof etc.] (v1) or Better a small bird (blue tit, magpie, sparrow etc.) in the hand than a larger bird [capercaillie (great grouse), crane, falcon, partridge, pigeon, stork etc.] in the air / skies / forest etc. (v2) or Better a chicken / sparrow / thrush today than a bustard / capercaillie / gander tomorrow (v3) or Better an egg today than a hen tomorrow (v4) (Paczolay, 1997: 194), где пословичная образность создаётся при помощи зоонимического (преимущественно орнитологического) кода в разнообразных сочетаниях с другими кодами (соматическим, флористическим, природным и др.) в контексте логической оппозиции «малое» vs. «большое» в проекции на аксиологически значимую мифологему «своё» vs. «чужое», ср.: бел. Лепш мець вераб’я ў руцэ, чым арла на суку = болг. По-добре сврака в pъка, а не сокол в гора = польск. Lepszy wróbel / gołąb w ręku niż sokół / cietrzew / bażant na sęku; Lepszy wróbel w garści niż gołąb / kanarek na dachu = рус. Лучше воробей в руке, чем петух на кровле; Лучше синица в руках (в руки), чем журавль в небе = слов. Lepši vrabec v hube, ako / než holub na dube = чеш. Lepši vrána v pytli jedna, nеž na vrbé tři = укр. Лучче синиця в жмени, ніж журавель у небі = лат. Labāk zīle / zvirbulis rokā nekā mednis kokā = лит. Geriau žvirblis rankoj negu briedis girioj = англ. A sparrow in the hand is worth a pheasant that flies by; $A$ bird in the hand is worth two in the bush / wood; A feather in the hand is better than a bird in the air = Hem. Eine Meise in der Hand ist besser als ein Kranich in der Luft = исп. Más vale pájaro en mano que dos / ciento / buitre volando = ит. Un uccello in mano ne val due nel bosco = фp. Un oiseau dans la main vaut mieux que deux dans la haie = венг. Jobb ma egy veréb mint sem holnap egy túzok = фин. Parempi pyy pivossa kuin metso metsässä = тур. Bugünkü tavuk yarınkı kazdan ıyıdır / yeğdır (Strauss, 1994b: 21; Paczolay, 1997: 194-202; Котова, 2000: 140; Петрушэўская, 2020: 62-64).

Показательно, что орнитологический код составляет основу образности и в азиатских этнонациональных вариантах этой универсальной пословицы - в арабском, персидском, японском и др. языках (Paczolay, 1997: 201-202).

Тем более удивительной является актуализация в тувинской пословице в качестве главной и единственной образной основы гастрономического кода, который встречается в европейских пословицах лишь в единичных случаях, только на втором плане (через коннотации) и в сочетании с орнитологическим кодом, напр.: = англ. Better an egg today than a hen tomorrow ‘Лучше яйцо сегодня, чем курица завтра' = фр. Un oeuf aujourd’hui vaut mieux qu'un poulet demain - 'Яйцо сегодня лучше, чем курица завтра' (Paczolay, 1997: 195, 200) = исп. Más vale el hueso de hoy, que no el pollo de mañana ‘Лучше сегодня 
кость, чем курица завтра' (Strauss, 1994a: 21). Такие пословицы образуют отдельный, представленный в небольшом количестве европейских языков вариант (v4) структурно-семантической модели данной универсальной пословицы, в котором аксиологически значимая мифологема «своё» vs. «чужое» реализуется не в пространственном отношении - «здесь» vs. «далеко» (как в пословичных вариантах с базовой орнитологической образностью), а во временном плане - «сейчас» vs. «в будущем».

Противопоставление «сало» vs. «лёгкое» в тувинской пословице вовсе не случайно, оно отражает типичное для этнокультурной картины мира кочевого народа отношение к жирной пище, которая очень ценится в условиях суровых погодных условий, долгих переходов и тяжёлого физического труда. Такое отношение зафиксировано во многих тувинских пословицах, где не только одобряется, но и восхваляется употребление в пищу жирного мяса и животного жира (в том числе и сала), напр.: Кылыр иштиң деги херек, чиир эъттиң чаглыы херек (с. 37) 'Для дела нужна быстрота, для еды жирное мясо’; Саасканның караа чаарда, чазыйның караа чагда (с. 48) 'Глаза сороки обманывают, глаза жадного - на сале'; Сөглээр сөстүң чигези херек, чиир эбттиң чаглыы херек (с. 50) 'Из сказанного слова нужна истина, из мяса - жир'; Чаашкынны үнүш күзээр, чаглыг эътти кижи күзээр (с. 62) Растение желает дождя, человек - жирное мясо’ и др. Образы «сало», «жир» в тувинских пословицах получили собственное осмысление и приобрели аксиологическую значимость не только в гастрономическом, но и в социокультурном плане как мерило смысла существования, благополучия в жизни, чести и достоинства, человеческих отношений (дружбы), напр.: Аң оруу - хан, мал оруу - чаг 'Путь зверя кровь, путь скота - сало’ (с. 15); Чаг иштинде бүүрек дег, чанчык иштинде таакпы дег (с. 63) ‘Как почка в сале, как табак в кисете’; Эки сөзүң эътке сатпа, чагыг сөзүң чага сатпа (с. 76) ‘Доброе слово не продавай за мясо, свой наказ не продавай за сало'; Эп бажы - чаг, сөс бажы - хан (с. 77) 'Начало дружбы -сало, начало слова - кровь' Тувинское чаг обозначает не свиное сало, типичное для кухни европейцев, а баранье (для свиного сала в тувинском языке есть отдельная номинация хаван чаa). Образ «сало» (как и образ «лёгкое») репрезентирует этнокультурную специфику тувинской пословицы на фоне аналогичных по структурно-семантической модели пословичных единиц как европейских, так и ряда азиатских языков.

Тувинскую пословицу о явном преимуществе на обеденном столе лёгких сегодня перед завтрашним салом можно квалифицировать как уникальный этнонациональный вариант зафиксированной в 50 европейских и азиатских языках универсальной пословицы (Strauss, 1994b: 21; Paczolay, 1997: 201-202), который не только существенно дополняет, но и расширяет азиатский ареал её распространения (впервые в таком качестве вводится в научный оборот при типологическом описании пословиц языков мира).

\section{Этнолингвокультурологический комментарий тувинских пословиц, которые имеют коррелятивные ключевые понятия и образы в европейских пословицах}

Содержание этнолингвокультурологического комментария тувинских пословиц, специфичных по структурно-семантической модели, но имеющих корреляции с европейскими пословицами по отдельным ключевым понятиям и / или пословичным образам, целесообразно ориентировать на выявление этнонационального своеобразия тувинских коррелятов, обусловленного как традиционной, так и современной культурой тувинского народа.

В нескольких тувинских пословицах используется образ «хлеб» как мерило благополучия (сытости), напр.: Тараалыгда - тодуг, дагаалыгда - сергек (с. 51) 'С хлебом сыт, с петухом - бодрствуешь', тараалыг кижи тодуг, адалыг кижи чоргаар 'Человек с хлебом сыт, с отцом - горд’ (с. 51). В таком качестве этот образ является типичным для европейских пословиц, в которых выступает одним из основных гастрономических образов, символизирующих 'богатство', 'достаток', 'сытость', 'радость' (Нелюбова, Сёмина, Казлаускене, 2020: 984). Представление о богатстве и сытости у тувинцев также связывается с хлебом (Курбатский, 2001: 51), однако вовсе не имеет, как может показаться на первый взгляд, той значимости, которая характерна для многих европейских народов.

Образ «хлеб» как символ благополучия коррелятивен, но не аналогичен в тувинских и европейских пословицах по своей аксиологической значимости, поскольку в европейской пословичной картине мире занимает аксиологически доминантную позицию, а в тувинской заменяется образами «мясо» и «сало». Именно поэтому в пословицах с логической структурой предпочтительного выбора «Лучше это здесь (сейчас), чем другое далеко (в будущем)» в европейских языках используется символ «хлеб», 
например, англ. Half a loaf is better than no bread 'Лучше половина буханки, чем вообще без хлеба', а в тувинском, соответственно, символика мясного изобилия, например, как в пословице Даартагы чагдан бөгүнгу өкпе дээре ‘Завтрашнего сала сегодняшние лёгкие лучше' (с. 23).

В тувинских пословицах, как и во всех европейских, присутствует «конь» в качестве и ключевого понятия, и зооморфного образа, однако реализация его отличается как в количественном, так и в качественном плане. Само по себе такое отличие является вполне объяснимым различными условиями жизни европейских и азиатских народов (как правило, соответственно, оседлых и кочевых), но при этом, на первый взгляд, далеко не кардинальным на фоне ожидаемой аксиологической близости в оценке значимости коня как одного из основных домашних животных. Тем более неожиданной оказывается огромная разница в квантитативных и квалитативных параметрах репрезентации коня при сравнении тувинского и европейских пословичных фондов.

Так, в 106 универсальных структурно-семантических моделях пословиц свыше 50 европейских языков зафиксировано всего 4 случая использования понятия и образа horse / mare ('конь / кобыла') в сочетании с fat ('тучный'), gift ('подарок'), stumble ('спотыкаться'), smith ('кузнец') (Paczolay, 1997). В одном произвольно взятом современном европейском языке, например, в белорусском, в составе пословичного минимума и основного пословичного фонда (наиболее известных и употребительных пословиц в синхроническом и диахроническом планах) на более чем 700 единиц зафиксировано всего $2 \%$ пословиц с конь / кабыла в сочетании с воз, хамут, зубы, спатыкацца, лечаны, аб’ехаць, тучны, paбы, капыты, чужы, кульгавы, дарога, запрагаць, дом (Ivanov, 2002: 5-20, 41-84).

В тувинских пословицах, которые были охвачены в данном исследовании, аът / конь встречается, во-первых, гораздо чаще (в среднем в более $6 \%$ единиц), а во-вторых, в более разнообразных качествах, ролях, взаимосвязях. Так, только атрибутивных характеристик $а б т$ / конь в тувинских пословицах представлено около десяти, напр.: ала аът 'пегий конь', карактыг аът 'зоркий конь' ““Але” дээр кижи авыяастыг, ала карактыг абт дезиг' (с. 15); хоюган аът 'пугливый конь' 'Өөренмээн абт хоюган болур' (с. 45), Хоюган абттың караа көскү, кортук кижиниң кулаа дыыжы (с. 59) 'У пугливого коня глаза зорки, у трусливого человека уши остры'; чоржаң аът 'ленивый конь' - Харам кижээ эш ырак, чоржаң аътка чер ырак (с. 57) ‘букв. От жадного друзья далеки, от ленивого коня - местность’, Чок чүвени бар диве, чоржаң, абтты маңныг диве (с. 67) 'Не говори, когда у тебя нет того, что есть, а ленивого коня не говори, что он скакун'; Кижиде багай чок, автта чоржаң чок (с. 106) 'Не бывает плохих людей, не бывает ленивых лошадей'; буруучал авт 'упрямый конь' - Хаттыг чаашкын аязыычал, халымак авт буруучал (с. 57) 'букв. Быстро прояснивается дождь с ветерком, легкомысленная лошадь - упрямым’; шодаң абт '(фолькл.) бесхвостый конь' - Шодаң аскыр аътка каржы, чолдак бижек холга каржы (с. 72) ‘Бесхвостый конь жесток к коню, короткий нож - руке’; эки аът 'хороший (добрый) конь' - Эки аът орук часпас, өдүрек куш хөл часпас (с. 75) 'Хороший конь не сбивается с пути, утка - озеро’; Эки кижээ эш хөй, эки аътка ээ хөй (с. 76) 'У хорошего человека много друзей, у доброго коня - хозяев'; тодар аът 'сытый конь' - Аът тодарга, хоюганы кончуг апаар, ыт тодарга, каржызы кончуг апаар (с. 87) 'Сытая лошадь становится пугливой, сытая собака - жестокой’; дезиг аът 'неуловимый конь (конь, которого трудно поймать)' - Дезиг аътка дезиг авт каттыжар, тенек кижиге тенек кижи каттыжар (с. 97) 'Неуловимые кони объединяются с неуловимыми, озорные люди - с озорными' и т. д.

Столь разительное отличие в репрезентации коррелятивного понятия и образа «конь» в тувинских и европейских пословицах объясняется тем, что в европейской традиционно-народной культуре (где рождались и употреблялись пословицы) отношение к коню как основному домашнему животному было, безусловно, очень бережным и даже трепетным, однако вместе с тем весьма прагматичным, не выходящим за рамки хозяйственных и транспортных нужд, а также военного дела, где конь долгое время играл ключевую роль. В силу этого конь противопоставлялся человеку, и в этой аксиологической оппозиции занимал доминантное положение - коня берегли часто даже в ущерб себе, что наиболее ярко отражено в такой интернациональной европейской пословице, не имеющей аналогов в тувинском языке, как бел. Баба з калёс - каню (калёсам) лягчэй = польск. Baba z woza, koniom lżej = pус Баба с возу коню легче = укр. Баба з воза - кобилі легше = лит. Boba iš vežimo - kumelei lengviau $=$ нем. Wenn das Weib von der Fuhre absteigt, hat es das Pferd leichter (Петрушэўская, 2020: 118). Однако «европейский» конь никогда не рассматривался в пословицах как неотъемлемый элемент жизни человека.

Совсем другое отношение к коню в тувинской пословичной картине мира, где он традиционного занимает гораздо более важное место не только в условиях кочевого образа жизни, но и в духовной 
культуре тувинского народа, не противопоставляется человеку, а уподобляется ему, понимается как единое целое с человеком, без чего человек не может существовать (Даржа, 2003). Наиболее ярко это отражено в пословице Аът - кижиниң буду, ыт - кижиниң кулаа 'Лошадь - нога человека, собака уши' (с. 87).

Конь принадлежит только мужчине и отождествляется с ним: Кыс этке ынак, оол аътка ынак (с. 38) 'Девушка любит вещи, парень - коня'; Инээм өдээ - ием чурту, аъдым өдээ - адам чурту (с. 102) 'Навоз коровы - родина матери, навоз коня - родина отца’. Конь незаменим для пастуха и для охотника, сравнивается по своей важности с отцом, с другом, напр.: Ада турда - чон таныыр, аът турда - чер көөр (с. 12) ‘С отцом - знать людей, с конем - видеть места’; Ада чокта - эш чок, аъды чокта - бут чок дег (с. 12) ‘Без отца - нет друзей, без коня как без ног’; Авттыг мен дээш адыыргава, эштиг мен дээш эшкеденме 'Не кичись, что имеешь коня, не чванись, что имеешь друга' (с. 88).

Хорошим конём гордятся, по праву хвастаются: Абды чүгүрүк мактадыр, ады чүгүрүк хоптадыр Добрый конь славы прибавляет, имя громкое зависть рождает (с. 13); Артык тенек аъдын мактаар, болбас тенек бодун мактаар - Хвастун хвалит своего коня, глупец хвалит самого себя (с. 16). В то же время плохого коня не стыдятся: Чаваа-даа бол, абды херек, чалчай-даа бол, эзери херек (с. 63) 'Даже если стригунок, но нужен свой, даже если седло, но нужен свой'.

Жизнь человека проецируется на образ жизни коня, напр.: Абт болуру кулунундан, кижи болуру чажындан 'Конь вырастает из жеребёнка, человек из малого ребёнка' (с. 17); Аът өлүр - баглаажы apmap, ада өлүр - оглу артар ‘Конь падёт - коновязь останется, отец умрёт - сын останется’ (с. 17); Өлген кижээ читкен аът айтыр ‘Покойного хороня, посулят ему пропавшего коня’ (с. 44); Ада орнун оол салгаар, аът орнун кулун салгаар ‘Место отца наследует сын, как жеребёнок - коня’ (с. 82).

Конь выступает мерилом физических и личностных качеств, социального поведения, достижения жизненных целей, духовных стремлений человека, напр.: Aътmы баглап өөредир, аныяан сургап өөредир (с. 18) 'Коня учат, привязывая, молодых учат словами'; Даг автты човадыр, кылык ботту човадыр 'Крутая гора коня измучает, тяжёлый нрав человека измучает' (с. 23); Кижи чугаалажып таныжар, аът киштежип таныжар (с. 33) ‘Люди, разговаривая, знакомятся, кони ржанием знакомятся’; Кижи экизи - найыралда, аът экизи - мунушта 'Преимущество человека в дружбе, преимущество коня в быстроходности’ (с. 34); Ушкарганнай улузунга чедирер, аъткарганнай аалынга чедирер 'За седлом посадил - довези до родни, посадил на коня - довези до аала’ (с. 54); Харам кижээ эш ырак, чоржаң аътка чер ырак 'Скупому человеку - товарища нет, ленивому коню - путь далёк’ (с. 57); Чаражынга шай хайындырбас, чажынга аът өртевес 'На красоте чая не сваришь, к косе коня не привяжешь' (с. 64); Эки аъдыңны дагга кызава, эки эжиңни чокка кызава 'Доброго коня в гору не погоняй, доброго друга отказом не огорчай’ (с. 75); Эки кижээ эш хөй, эки аътка ээ хөй ‘У доброго человека много друзей, у доброго коня много седоков’ (с. 76); Дезиг аътка дезиг аът каттыжар, тенек кижиге тенек кижи каттыжар 'К неуловимому коню неуловимый примыкает, неугомонный человек с неугомонным сходится' (c. 97).

Кроме того, понятие и образ «конь» часто используется в тувинских пословицах, аналогичных иноязычным по структурно-семантической модели, в качестве этнолингвомаркера (термин О. В. Ломакиной). Напр.: Хоюган аъттың караа көскү, кортук кижиниң кулаа дыыжы (с. 59) 'У пугливого коня глаза зоркие, у трусливого человека слух обострен’, ср. = бел. Баязліуцу і корч мядзведзь = рус. Трусливому зайке и пенек - волк = укр. Боязливому і копа здається стогом (Петрушэусккая, 2020: 120). Также: Эртежи кижи эзерлиг абтка таваржыр 'Кто рано поутру встаёт, коня с седлом себе найдёт' (с. 77), ср. = бел. Хто рана ўстае, таму і Бог дае = польск. Kto rano wstaje, temu Pan Bóg daje = pус. Кто рано встаёт, тому Бог подаёm = укр. Хто рана встає, тому Бог дає = англ. God gives help to early risers = нем. Früh auf, gut Lauf = исп. Más vale a quien Dios ayuda que a quien mucho madruga; A quien madruga, Dios le ayuda = фp. A bon gain qui se lève matin; Qui se lève le matin Dieu prête la main (Петрушэўская, 2020: 290-291). Это ещё раз свидетельствует об этнокультурной специфике понятия и образа «конь» в пословичной картине мира тувинского народа на фоне паремиологического континуума европейских языков и культур.

\section{Заключение}

Принципы и содержание словарного описания тувинских пословиц на европейском языковом фоне детерминированы необходимостью представления в полилингвальном паремиологическом слова- 
ре различной по типу и объёму лексикографически значимой информации, которая дифференцируется по четырём основным зонам.

Зона реестровой единицы последовательно репрезентирует три типа информации о тувинской пословице: её формальные варианты; аутентичный перевод на русский и английский языки; указание на общность / специфичность её структурно-семантической модели, а также полной / частичной аналогии, абсолютной / коррелятивной уникальности её ключевых понятий и / или пословичных образов. Учёт формальных вариантов пословицы и аутентичность её перевода позволяет максимально полно и объективно выявить и описать этнолингвокультурную специфику тувинских пословиц, их типологическую общность / близость с пословицами других языков (на европейском языковом фоне).

Зона иноязычного аналога или коррелята представляет европейскую пословицу, аналогичную или близкую по структурно-семантической модели реестровой тувинской пословице, а также европейскую пословицу, которая является коррелятивной реестровой тувинской пословице по соотносимым ключевым понятиям и / или пословичным образам (включая при этом указание на характер аналогии или корреляции - универсальный, интернациональный, этнонациональный).

Зона этнолингвокультурологического комментария содержит описание структурно-семантической модели, перечень ключевых понятий, пословичных образов, а также характеристики этнолингво- / этнокультурной ассимиляции / корреляции реестровой тувинской пословицы в сопоставлении с аналогичной или коррелятивной европейской пословицей.

Зона парадигматических связей в тувинском языке отражает синонимы, антонимы, ассоциативно близкие пословицы по структурно-семантической модели, ключевым понятиям, пословичным образам, что представляется важным для дифференциации типологически общего (близкого) с другими языками и этнонационально-специфического в структуре всего тувинского пословичного фонда.

Перспективой для дальнейших исследований является разработка конкретных приёмов словарного описания тувинских пословиц на широком европейском языковом фоне в рамках отдельных лексикографических зон и создание на этой основе первого в мировой лексикографии тувинско-иноязычного паремиологического словаря с этнолингвокультурологическим комментарием (на фоне современных европейских языков).

Лексикографическое описание тувинских пословиц в сопоставлении с европейскими позволит впервые ввести тувинский пословичный фонд в научный оборот при дескриптивном, сопоставительном и типологическом изучении пословиц европейских языков, что создаст новые предпосылки для развития исследований паремиологических универсалий и уникалий, места и роли тувинского языка и фольклора в широком евроазиатском языковом и лингвокультурном пространстве.

\section{СПИСОК ЛИТЕРАТУРЫ}

Болат-оол, Р. В., Пелевина, Н. Н. (2017) Формирование образа женщины в тувинских и немецких пословицах // Вестник Хакасского государственного университета им. Н. Ф. Катанова. № 21. С. 29-32.

Бредис, М. А., Ломакина, О. В., Мокиенко, В. М. (2019) Пословица в современной лингвистике: определение, статус, функционирование // Вестник Московского университета. Серия 19: Лингвистика и межкультурная коммуникация. № 3. С. 34-43.

Бредис, М. А., Ломакина, О. В., Мокиенко, В. М. (2020) Русинская фразеология как пример культурно-языкового трансфера в славянских языках (на материале нумеративных единиц) // Русин. № 60. C. 198-212. DOI: https:// www.doi.org/10.17223/18572685/60/12

Бредис, М. А., Димогло, М. С., Ломакина, О. В. (2020) Паремии в современной лингвистике: подходы к изучению, текстообразующий и лингвокультурологический потенциал // Вестник Российского университета дружбы народов. Серия: Теория языка. Семиотика. Семантика. Т. 11. № 2. С. 265-284. DOI: https://www.doi.org/10.22363/23132299-2020-11-2-265-284

Будегечиева, Т. Б. (2018) Тувинская культура: материальное и духовное, традиции и новации. Кызыл : Изд-во ТувГУ. 115 с.

Бурыкин, А. А., Болдырева, И. М., Музраева, Д. Н. (2019) Собака в калмыцком и тувинском фольклоре // Новые исследования Тувы. № 4. С. 119-132. DOI: https://www.doi.org/10.25178/nit.2019.4.10 
Галиуллин, К. Р. (2018) Татар фольклоры теле: мәкальләр, канатлы әйтелмәләр, жор сүзләр һәм әйтемнәр: сүзлек = Язык татарского фольклора: пословицы, крылатые выражения, присловья и поговорки: словарь. Казан : ТӘһСИ. 588 с.

Даржа В. К. (2003) Лошадь в традиционной практике тувинцев-кочевников / отв. ред. Г. Н. Курбатский. Кызыл : ТувИКОПР СО РАН. 154 с.

Доржу, К. Б. (2012) Сравнения в русских и тувинских поговорках, порицающих отрицательные качества человека // Вестник Тувинского государственного университета. № 1. С. 94-98.

Егорова, А. И., Кондакова, А. П., Кужугет, М. А. (2020) Гендерные стереотипы в тувинских пословицах и поговорках // Новые исследования Тувы. № 1. С. 18-31. DOI: https://www.doi.org/10.25178/nit.2020.1.2

Иванов, Е. Е. (2009) Критерии систематизации афористического материала как объекта лексикографического описания // Journal of Historical, Philological and Cultural Studies. № 2 (24). С. 88-91.

Иванов, Е. Е. (2019а) Аспекты эмпирического понимания афоризма // Вестник Российского университета дружбы народов. Серия: Теория языка. Семиотика. Семантика. T. 10. № 2. C. 381-401. DOI: https://www.doi. org/10.22363/2313-2299-2019-10-2-381-401

Иванов, Е. Е. (2019b) О рекуррентности афористических единиц в современном русском языке // Русистика. T. 17. № 2. С. 157-170. DOI: https://www.doi.org/10.22363/2618-8163-2019-17-2-157-170

Иванов, Е. Е. (2020) Афоризм как объект лингвистики: основные признаки // Вестник Российского университета дружбы народов. Серия: Теория языка. Семиотика. Семантика. Т. 11. № 4. C. 659-706. DOI: https://www.doi. org/10.22363/2313-2299-2020-11-4-659-706

Иванов, Е. Е., Ломакина, О. В., Нелюбова, Н. Ю. (2021) Семантический анализ тувинских пословиц: модели, образы, понятия (на европейском паремиологическом фоне) // Новые исследования Тувы. № 3. C. 220-233. DOI: https://www.doi.org/10.25178/nit.2021.3.17

Іванова, С., Іваноў, Я. (1997) Слоўнік беларускіх прыказак, прымавак і крылатых выразаў. Мінск : БФС. 262 с. (На белорус. яз.)

Іваноў, Я. Я., Петрушэўская, Ю. А. (2021) Асноўныя кампаненты прыказкі як моўнай адзінкі: прыказкавая структурна-семантычная мадэль // Весці БДПУ. № 3. С. 104-110. (На белорус. яз.)

Кечил-оол, С. В., Саая, О. М. (2016) Особенности фразеологизмов с компонентом «ухо» в тувинском языке в сопоставлении с русским // Филологические науки. Вопросы теории и практики. № 9-2(63). С. 107-109.

Кечил-оол, С. В., Саая, О. М. (2017) Семантические особенности фразеологизмов с компонентом «рука» в тувинском и русском языках // Филологические науки. Вопросы теории и практики. № 6-1(72). С. $92-95$.

Коняшкин, А. М., Чадамба, Ш. С. (2014а) О некоторых особенностях введения паремий в художественный текст (на материале русских переводов) // Мир науки, культуры, образования. № 3(46). С. 200-202.

Коняшкин, А. М., Чадамба, Ш. С. (2014b) Проблема перевода тувинских паремий (на материале русских художественных переводов) // Мир науки, культуры, образования. № 3(46). С. 202-204.

Коняшкин, А. М., Чадамба, Ш. С. (2017) Лингвокультурологический аспект тувинских паремий в текстах русских художественных переводов // Мир науки, культуры, образования. № 6 (67). С. 616-618.

Котова, М. Ю. (2000) Русско-славянский словарь пословиц (с английскими соответствиями). СПб. : Изд-во СПбГУ. 360 с.

Курбатский, Г. Н. (2001) Тувинцы в своем фольклоре (историко-этнографические аспекты тувинского фольклора). Кызыл : Тувинское книжное издательство. 464 с.

Ламажаа, Ч. К. (2015) Ребёнок и детство в тувинской культуре: традиции и современность // Человек. № 4. C. 51-58.

Лепта библейской мудрости: русско-славянский словарь библейских выражений и афоризмов с соответствиями в германских, романских, армянском и грузинском языках (2019а) : в 2 т. / 3. К. Адамия и др. Могилёв : МГУ. T. 1.288 с.

Лепта библейской мудрости: русско-славянский словарь библейских выражений и афоризмов с соответствиями в германских, романских, армянском и грузинском языках (2019b) : в 2 т. / З. К. Адамия и др. Могилёв : МГу. T. 2. 308 c.

Ломакина, О. В., Мокиенко, В. М. (2016) Познавательный потенциал русинских паремий на фоне русского и украинского языков // Русин. № 3(45). С. 119-128. DOI: https://www.doi.org/10.17223/18572685/45/9

Ломакина, О. В., Мокиенко, В.М. (2018) Ценностные константы русинской паремиологии (на фоне украинского и русского языков) // Русин. № 4(54). С. 303-317. DOI: https://www.doi.org/10.17223/18572685/54/18 
Мокиенко, В. М., Никитина, Т. Г., Николаева, Е. К. (2010) Большой словарь русских пословиц. М. : ОЛМА Медиа Групп. 1024 с.

Нелюбова, Н. Ю. (2019) Семья как общечеловеческая ценность во французской и русской пословичной картине мира // Филологические науки. Научные доклады высшей школы. № 6. С. 50-59.

Нелюбова, Н. Ю., Сёмина, П. С., Казлаускене, В. (2020) Гурманство в иерархии ценностей французов и бельгийцев (на материале пословиц и поговорок) // Russian Journal of Linguistics. T. 24. № 4. C. 969-990. DOI: https://www. doi.org/10.22363/2687-0088-2020-24-4-969-990

Нелюбова, Н. Ю., Хильтбруннер, В. И., Ершов, В. И. (2019) Отражение иерархии ценностей в пословичном фонде русского и французского языков // Вестник Российского университета дружбы народов. Серия: Лингвистика = Russian Journal of Linguistics. T. 23. № 1. C. 223-243. DOI: https://www.doi.org/10.22363/2312-9182-2019-23-1-223-243

Паремиология без границ (2020) / ред. М. А. Бредис, О. В. Ломакина. М. : Изд-во РУДН. 244 с.

Паремиология в дискурсе (2015) / ред. О. В. Ломакина. М. : URSS ; Ленанд. 294 с.

Петрушевская, Ю. А. (2021) Методология определения национального, интернационального и универсального в фразеологии и паремиологии белорусского языка // West - East. Vol. 5. № 1. Pp. 61-72.

Петрушэўская, Ю. А. (2020) Універсальны і інтэрнацыянальны кампаненты ў парэміялагічным складзе беларускай мовы: беларуска-іншамоўны слоўнік. Магілёў : МДУ. 312 с. (На белорус. яз.)

Салчак, А. М. (2019) Образ волка в тувинских и английских пословицах // Символ науки: международный научный журнал. № 6. С. 25-27.

Селиверстова, Е. И. (2009) Опыт выявления пословичного бинома и проблема вариантности // Русский язык в научном освещении. № 1(17). С. 182-200.

Татарские народные пословицы и поговорки (2020) / сост. Л. Х. Мухаметзянова, И. И. Ямалтдинов. Казань : Татарское книжное издательство. 301 с.

Тувинско-русский словарь (1968) / под ред. Э. Р. Тенишева. М. : Сов. энциклопедия. 648 с.

Тувинско-русский словарь (2014). 2-е изд. / рук. Э. Р. Тенишев, Д. А. Монгуш. Кызыл : ОАО «Тываполиграф». 648 с.

Чадамба, Ш. С. (2014) О некоторых особенностях перевода предложений-паремий в текстах русских художественных переводов с тувинского языка // Филологические науки. Вопросы теории и практики. № 5-1(35). С. 191-193.

Чадамба, Ш. С. (2015) Предложения-паремии в текстах русских художественных переводов с тувинского языка : дисс.... канд. филол. наук. Абакан. 151 с.

Чугунекова, А. Н. (2019) Символика чисел в хакасской и тувинской паремиологии // Международный журнал гуманитарных и естественных наук. № 10-2(37). С. 18-21.

Grigas, K. (1987) Patarlių paralelès. Lietuvių patarlès su latvuių, baltarusių, rusų, lenkų, vokiečių, anglų, lotynų, prancūzų, ispanų, atitikmenimis. Vilnius : Leydykla Vaga. 662 s. (На литов. яз.)

Ivanov, E. (2002) Paremiological Minimum and Basic Paremiological Stock (Belarusian and Russian). Prague : RSS. $136 \mathrm{p}$.

Ivanov, E., Feldman, V. (2007) Principles of the Contrastive Description of Aphoristic Paremiology (in Belarusian and Russian Languages) // Acta Germano-Slavica. Vol. 1. Pp. 85-97.

Ivanov, E., Petrushevskaia, Ju. (2015) Etymology of English Proverbs // Journal of Siberian Federal University. Humanities \& Social Sciences. Vol. 8. № 5. Pp. 864-872.

Lomakina, O. V. (2021) Concepts of god and faith in Uzbek and Tajik proverbs in terms of culture and language transfer theory // European Journal of Science and Theology. Vol. 17. № 2. P. 125-135.

Muñoz, J. S. (2001) 1001 refranes españoles con su correspondencia en ocho lenguas (alemán, árabe, francés, inglés, italiano, polaco, provenzal y ruso). S. A. Eiunsa : Ediciones Internacionales Universitarias. 444 р. (На исп. яз.)

Paczolay, G. (1997) European Proverbs in 55 Languages, with Equivalents in Arabic, Persian, Sanskrit, Chinese, and Japanese. Veszprém (Hungary) : Veszprémi Nyomda. 528 p.

Strauss, E. (1994a) Dictionary of European Proverbs : in 3 vol. London \& New York : Routledge. Vol. 2.2020 p.

Strauss, E. (1994b) Dictionary of European Proverbs : in 3 vol. London \& New York : Routledge. Vol. 3. 798 p.

Дата поступления: 15.09.2021 2. 


\section{REFERENCES}

Bolat-ool, R. V. and Pelevina, N. N. (2017) Formirovanie obraza zhenshchiny v tuvinskikh i nemetskikh poslovitsakh [On woman's image in Tuvan and German proverbs]. Vestnik Khakasskogo gosudarstvennogo universiteta im. N. F. Katanova, no. 21, pp. 29-32. (In Russ.)

Bredis, M. A., Lomakina, O. V. and Mokienko, V. M. (2019) Poslovitsa v sovremennoi lingvistike: opredelenie, status, funktsionirovanie [The proverb in modern linguistics: definition, status, and functioning]. Vestnik Moskovskogo universiteta. Seriia 19: Lingvistika i mezhkul'turnaia kommunikatsiia, no. 3, pp. 34-43. (In Russ.)

Bredis, M. A., Lomakina, O. V. and Mokienko, V. M. (2020) Rusinskaia frazeologiia kak primer kul'turno-iazykovogo transfera v slavianskikh iazykakh (na materiale numerativnykh edinits) [Rusin phraseology as an example of cultural and linguistic transfer in Slavic Languages: The case of numeration units)]. Rusin, no. 60, pp. 198-212. (In Russ.) DOI: https:// www.doi.org/10.17223/18572685/60/12

Bredis, M. A., Dimoglo, M. S. and Lomakina, O. V. (2020) Paremii v sovremennoi lingvistike: podkhody k izucheniiu, tekstoobrazuiushchii i lingvokul'turologicheskii potentsial [Paremias in modern linguistics: Approaching their study, text-building and linguocultural potential.]. RUDN Journal of Language Studies, Semiotics and Semantics, vol. 11, no. 2, pp. 265-284. (In Russ.) DOI: https://www.doi.org/10.22363/2313-2299-2020-11-2-265-284

Budegechieva, T. B. (2018) Tuvinskaia kul'tura: material'noe i dukhovnoe, traditsii i novatsii [Tuvan culture: the material and the spiritual, traditions and innovations]. Kyzyl, TuvGU Publ. 115 p. (In Russ.)

Burykin, A. A., Boldyreva, I. M. and Muzraeva, D. N. (2019) Sobaka v kalmytskom i tuvinskom fol'klore [The dog in Kalmyk and Tuvan folklore]. New Research of Tuva, no. 4, pp. 119-132. (In Russ.). DOI: https://www.doi.org/10.25178/ nit.2019.4.10

Galiullin, K. R. (2018) Tatar fol'klory tele: məkal'lər, kanatly əitelmələr, ж,or süzlər həm əitemnər: süzlek= Iazyk tatarskogo fol'klora: poslovitsy, krylatye vyrazheniia, prislov'ia i pogovorki: slovar' [The language of Tatar folklore: proverbs, proverbial expressions, bywords and sayings: a dictionary]. Kazan, TəhSI. 588 b. (In Tat.)

Darzha, V. Ch. (2003) Loshad'v traditsionnoi praktike tuvintsev-kochevnikov [The horse in the traditional practice of the Tuvan nomads] / ed. by G. N. Kurbatskii. Kyzyl, TuvIKOPR SO RAN. 184 p. (In Russ.).

Dorzhu, K. B. (2012) Sravneniia v russkikh i tuvinskikh pogovorkakh, poritsaiushchikh otritsatel'nye kachestva cheloveka [Comparisons in Russian and Tuvan sayings that condemn negative qualities of a person]. Vestnik Tuvinskogo gosudarstvennogo universiteta, no. 1, pp. 94-98. (In Russ.)

Egorova, A. I., Kondakova, A. P. and Kuzhuget, M. A. (2020) Gendernye stereotipy v tuvinskikh poslovitsakh i pogovorkakh [Gender stereotypes in Tuvan proverbs and sayings]. New Research of Tuva, no. 1, pp. 18-31. (In Russ.). DOI: https://www.doi.org/10.25178/nit.2020.1.2

Ivanov, E. E. (2009) Kriterii sistematizatsii aforisticheskogo materiala kak ob"ekta leksikograficheskogo opisaniia [Aphorism as the object of lexicographic description: criteria of systematization]. Journal of Historical, Philological and Cultural Studies, no. 2 (24), pp. 88-91. (In Russ.)

Ivanov, E. E. (2019a) Aspekty empiricheskogo ponimaniia aforizma [Aspects of empirical understanding of aphorisms]. RUDN Journal of Language Studies, Semiotics and Semantics, vol. 10, no. 2, pp. 381-401. (In Russ.). DOI: https://www.doi. org/10.22363/2313-2299-2019-10-2-381-401

Ivanov, E. E. (2019b) O rekurrentnosti aforisticheskikh edinits v sovremennom russkom iazyke [Aphoristic units and their recurrence in modern Russian language]. Russian Language Studies, vol. 17, no. 2, pp. 157-170. (In Russ.). DOI: https:// www.doi.org/10.22363/2618-8163-2019-17-2-157-170

Ivanov, E. E. (2020) Aforizm kak ob'ekt lingvistiki: osnovnye priznaki [Aphorism as an object of linguistics: the main properties]. RUDN Journal of Language Studies, Semiotics and Semantics, vol. 11, no. 4, pp. 659-706. (In Russ.). DOI: https:// www.doi.org/10.22363/2313-2299-2020-11-4-659-706

Ivanov, E. E., Lomakina, O. V. and Nelyubova N. Yu. (2021) Semanticheskii analiz tuvinskikh poslovits: modeli, obrazy, poniatia (na evropeiskom paremiologicheskom fone) [Semantic analysis of Tuvan proverbs: models, imagery, concepts (against the European paremiological background)]. New Research of Tuva, no. 3, pp. 232-248. (In Russ.). DOI: https:// www.doi.org/10.25178/nit.2021.3.17

Ivanova, S. and Ivanoy̆, Ia. (1997) Sloy̆nik belaruskikh prykazak, prymavak i krylatykh vyrazay̆ [A dictionary of Belarusian proverbs, sayings and catch phrases]. Minsk, BFS. 262 p. (In Bel.)

Ivanoy̆, Ya. Ya. and Petrushey̆skaia, Yu. A. (2021) Asnoy̆nyia kampanenty prykazki iak moy̆nai adzinki: prykazkavaia strukturna-semantychnaia madel' [The main components of a proverb as a linguistic unit: a proverbial structural and semantic model]. Vestsi BDPU, no. 3, pp. 104-110. (In Bel.) 
Kechil-ool, S. V. and Saaia, O. M. (2016) Osobennosti frazeologizmov s komponentom «ukho» v tuvinskom iazyke v sopostavlenii s russkim [Specifics of phraseological units with the component "ear" in the Tuvan language in comparison with the Russian]. Filologicheskie nauki. Voprosy teorii i praktiki, no. 9-2(63), pp. 107-109. (In Russ.)

Kechil-ool, S. V. and Saaia, O. M. (2017) Semanticheskie osobennosti frazeologizmov s komponentom «ruka» v tuvinskom i russkom iazykakh [The semantic peculiarities of phraseological units with the component "Hand" in Tuvan and Russian languages]. Filologicheskie nauki. Voprosy teorii i praktiki, no. 6-1(72), pp. 92-95. (In Russ.)

Koniashkin, A. M. and Chadamba, Sh. S. (2014a) O nekotorykh osobennostiakh vvedeniia paremii v khudozhestvennyi tekst (na materiale russkikh perevodov) [Some aspects of introducing paroemias into a literary text: the case of Russian translations)]. Mir nauki, kul'tury, obrazovaniia, no. 3(46), pp. 200-202. (In Russ.)

Koniashkin, A. M. and Chadamba, Sh. S. (2014b) Problema perevoda tuvinskikh paremii (na materiale russkikh khudozhestvennykh perevodov) [The problem of translating Tuvan paroemias (on the material of Russian literary translations)]. Mir nauki, kul'tury, obrazovaniia, no. 3(46), pp. 202-204. (In Russ.)

Koniashkin, A. M. and Chadamba, Sh. S. (2017) Lingvokul'turologicheskii aspekt tuvinskikh paremii v tekstakh russkikh khudozhestvennykh perevodov [The linguoculturological aspect of Tuvan paroemias in their literary translations into Russian]. Mir nauki, kul'tury, obrazovaniia, no. 6 (67), pp. 616-618. (In Russ.)

Kotova, M. Yu. (2000) Russko-slavianskii slovar' poslovits (s angliiskimi sootvetstviiami) [A Russian-Slavic dictionary of proverbs, with their English correspondences]. St. Peterburg, SPbGU Publ. 360 p. (In Russ.)

Kurbatskii, G. N. (2001) Tuvintsy v svoem fol'klore (istoriko-etnograficheskie aspekty tuvinskogo fol'klora) [Tuvans in their folklore: Historical and ethnographic aspects of Tuvan folklore)]. Kyzyl, Tuva book publishing house. 464 p. (In Russ.).

Lamazhaa, Ch. K. (2015) Rebenok i detstvo v tuvinskoi kul'ture: traditsii i sovremennost' [The child and childhood in Tuvan culture: traditions and modernity]. Chelovek, no. 4, pp. 51-58. (In Russ.).

Lepta bibleiskoi mudrosti: russko-slavianskii slovar' bibleiskikh vyrazhenii i aforizmov s sootvetstviiami v germanskikh, romanskikh, armianskom i gruzinskom iazykakh [A mite of Biblical wisdom: A Russian-Slavic dictionary of Biblical expressions and aphorisms with their correspondences in Germanic, Romance, Armenian and Georgian languages] (2019): in 2 vols. Z. K. Adamya et al. Mogilev, MGU. $288+308$ p. (In Russ.)

Lomakina, O. V. and Mokienko, V. M. (2016) Poznavatel'nyi potentsial rusinskikh paremii na fone russkogo i ukrainskogo iazykov [Cognitive potential of Rusin proverbs compared with those in the Russian and Ukrainian languages]. Rusin, no. 3(45), pp. 119-128. (In Russ.). DOI: https://www.doi.org/10.17223/18572685/45/9

Lomakina, O. V. and Mokienko, V. M. (2018) Tsennostnye konstanty rusinskoi paremiologii (na fone ukrainskogo i russkogo iazykov) [Value constants of the Rusin paremiology (compared with the Ukrainian and Russian languages)]. Rusin, no. 4(54), pp. 303-317. (In Russ.). DOI: https://www.doi.org/10.17223/18572685/54/18

Mokienko, V. M., Nikitina, T. G. and Nikolaeva, E. K. (2010) Bol'shoi slovar' russkikh poslovits [The grand dictionary of Russian proverbs]. Moscow, OLMA Media Grupp. 1024 p. (In Russ.)

Neliubova, N. Yu. (2019) Sem'ia kak obshchechelovecheskaia tsennost' vo frantsuzskoi i russkoi poslovichnoi kartine mira [The family as a universal value in the French and Russian proverbial picture of the world]. Filologicheskie nauki. Nauchnye doklady vysshei shkoly, no. 6, pp. 50-59. (In Russ.)

Neliubova, N. Yu., Semina, P. S. and Kazlauskene, V. (2020) Gurmanstvo v ierarkhii tsennostei frantsuzov i bel'giitsev (na materiale poslovits i pogovorok) [Gourmandise in the hierarchy of values: A case study of French and Belgian proverbs and sayings]. Russian Journal of Linguistics, vol. 24, no. 4, pp. 969-990. (In Russ.) DOI: https://www.doi.org/10.22363/26870088-2020-24-4-969-990

Neliubova, N. Yu., Khil’tbrunner, V. I. and Ershov, V. I. (2019) Otrazhenie ierarkhii tsennostei v poslovichnom fonde russkogo i frantsuzskogo iazykov [The proverb corpora of Russian and French languages as a reflection of value hierarchies]. Russian Journal of Linguistics, vol. 23, no. 1, pp. 223-243. (In Russ.). DOI: https://www.doi.org/10.22363/2312-9182-201923-1-223-243

Paremiologiia bez granits [Paremiology without borders] (2020) / ed. by M. A. Bredis and O. V. Lomakina. Moscow, RUDN Publ. 244 p. (In Russ.).

Paremiologiia v diskurse [Paremiology in Discourse] (2015) / ed. by O. V. Lomakina. Moscow, URSS; Lenand. 294 p. (In Russ.).

Petrushevskaia, Yu. A. (2021) Metodologiia opredeleniia natsional'nogo, internatsional'nogo i universal'nogo v frazeologii i paremiologii belorusskogo iazyka [Methodology for determining the national and the international and universal in the phraseology and paremiology of the Belarusian language]. West - East, vol. 5, no. 1, pp. 61-72. (In Russ.). 
Petrushey̆skaia, Yu. A. (2020) Universal'ny i internatsyianal'ny kampanenty y̆ paremiialagichnym skladze belaruskai movy: belaruska-inshamoy̆ny sloy̆nik [Universal and international components in the paremiological composition of the Belarusian language: Belarusian-foreign language dictionary]. Magiley̆, MDU. 312 p. (In Bel.)

Salchak, A. M. (2019) Obraz volka v tuvinskikh i angliiskikh poslovitsakh [The wolf in Tuvan and English proverbs]. Simvol nauki: mezhdunarodnyi nauchnyi zhurnal, no. 6, pp. 25-27. (In Russ.).

Seliverstova, E. I. (2009) Opyt vyiavleniia poslovichnogo binoma i problema variantnosti [The experience of identifying the proverbial binomial and the problem of variation]. Russkii iazyk v nauchnom osveshchenii, no. 1(17), pp. 182-200. (In Russ.).

Tatarskie narodnye poslovitsy i pogovorki [Tatar folk proverbs and sayings] (2020) / comp. by L. Kh. Mukhametzianova and I. I. Iamaltdinov. Kazan', Tatar Book Publishing House. 301 p. (In Russ.)

Tuvinsko-russkii slovar' [A Tuvan-Russian Dictionary] (1968): c. 22000 words / ed. by E. R. Tenishev. Moscow, Sovetskaia entsiklopediia. 465 p. (In Russ. and Tuv.).

Tuvinsko-russkii slovar' [A Tuvan-Russian Dictionary] (2014). $2^{\text {nd }}$ ed. / ed. by E. R. Tenishev and D. A. Mongush. Kyzyl, OAO «Tyvapoligraf». 648 p. (In Russ. and Tuv.).

Chadamba, Sh. S. (2014) O nekotorykh osobennostiakh perevoda predlozhenii-paremii $\mathrm{v}$ tekstakh russkikh khudozhestvennykh perevodov s tuvinskogo iazyka [Some aspects of translating proverbial sentences in the texts of the Russian literary translations from the Tuvan language]. Filologicheskie nauki. Voprosy teorii i praktiki, no. 5-1(35), pp. 191-193. (In Russ.)

Chadamba, Sh. S. (2015) Predlozheniia-paremii v tekstakh russkikh khudozhestvennykh perevodov s tuvinskogo iazyka [Proverbial sentences in the texts of Russian literary translations from the Tuvan language]: Diss. ... Candidate of Philology. Abakan. 151 p. (In Russ.).

Chugunekova, A. N. (2019) Simvolika chisel v khakasskoi i tuvinskoi paremiologii [Numerical symbolism in Khakass and Tuvan paremiology]. Mezhdunarodnyi zhurnal gumanitarnykh i estestvennykh nauk, no. 10-2(37), pp. 18-21. (In Russ.)

Grigas, K. (1987) Patarliu paralelès. Lietuviu patarlès su latvuių, baltarusių, rusų, lenku, vokiečiu, anglu, lotynų, prancūzu, ispanu, atitikmenimis. Vilnius, Leydykla Vaga. 662 s. (In Lit.)

Ivanov, E. (2002) Paremiological minimum and basic paremiological stock in Belarusian and Russian). Prague, RSS. 136 p.

Ivanov, E. and Feldman, V. (2007) Principles of the contrastive description of aphoristic paremiology in Belarusian and Russian Languages. Acta Germano-Slavica, vol. 1, pp. 85-97.

Ivanov, E. and Petrushevskaia, Yu. (2015) Etymology of English Proverbs. Journal of Siberian Federal University, Humanities \& Social Sciences, vol. 8, no. 5, pp. 864-872.

Lomakina, O. V. (2021) Concepts of God and faith in Uzbek and Tajik proverbs in terms of culture and language transfer theory. European Journal of Science and Theology, vol. 17, no. 2, pp. 125-135.

Muñoz, J. S. (2001) 1001 refranes españoles con su correspondencia en ocho lenguas (alemán, árabe, francés, inglés, italiano, polaco, provenzal y ruso). S. A. Eiunsa : Ediciones Internacionales Universitarias. 444 p. (In Spanish)

Paczolay, G. (1997) European Proverbs in 55 Languages, with Equivalents in Arabic, Persian, Sanskrit, Chinese, and Japanese. Veszprém (Hungary), Veszprémi Nyomda. 528 p.

Strauss, E. (1994) Dictionary of European Proverbs : in 3 vols. London, New York, Routledge.

Submission date: 15.09.2021. 